\title{
Congenital haemolytic anaemia associated with abnormal inducible red cell cation permeability
}

\author{
R M GARDINER, N D BARNES, AND J C ELLORY \\ Department of Paediatrics, Addenbrooke's Hospital, Cambridge, and Physiological Laboratory, \\ University of Cambridge
}

SUMMARY Congenital haemolytic anaemia in a 14 year old girl was caused by increased red cell membrane cation permeability. Potassium permeability was unusually sensitive to hydrostatic pressure and treatment with $\mathrm{N}$-ethylmaleimide, factors which activate a specific chloride dependent potassium channel in cell membranes.

Abnormal red cell cation transport that occurs in association with haemolytic anaemia caused by various metabolic and haemoglobin disorders was first recognised as a primary cause of haemolytic anaemia by Oski et al. ${ }^{1}$ Their patient had stomatocytosis, an abnormality of red cell morphology that had previously been recorded in association with unexplained haemolytic anaemia. ${ }^{2}{ }^{3}$ It has since been recognised that a spectrum of abnormalities exists, with changes in red cell morphology determined by the resultant total red cell cation and water content. ${ }^{4}$ Thi: report describes a girl with congenital haemolytic anaemia whose red cells showed a mild increase only in permeability to sodium and potassium under normal conditions. However, an unusually large increase in potassium permeability occurred with increased hydrostatic pressure or with $\mathrm{N}$-ethylmaleimide. These factors activate a specific chloride dependent potassium channel in cell membranes.

\section{Case report}

The patient, a girl aged 14 years at the time of the study, was born at term of healthy unrelated Caucasian parents and weighed $3.2 \mathrm{~kg}$. The neonatal period was uneventful apart from transient mild jaundice. She presented at age 3 months with a history of poor feeding and inadequate weight gain. Pallor was obvious on physical examination but there was no jaundice or splenomegaly. Investigation showed anaemia, haemoglobin $6 \cdot 3 \mathrm{~g} / \mathrm{dl}$, and a reticulocytosis of $10 \%$. The direct Coombs's test and tests for maternal atypical antibodies and haemolysins were negative. She was treated on 5 occasions with intramuscular iron (Imferon $0.5 \mathrm{ml}$ ) followed by oral iron supplements. She was seen regularly over the next 15 months during which time she remained well and her haemoglobin fluctuated between $7.7 \mathrm{~g} / \mathrm{dl}$ and $9.5 \mathrm{~g} / \mathrm{dl}$. A provisional diagnosis of haemolysis or persistent occult blood loss was made.

She was lost to follow up and did not come to medical attention again until she was aged 10 years when she presented with abdominal pain. There was a 6 month history of intermittent colicky, epigastric abdominal pain associated with nausea and vomiting. Pallor, mild icterus, and splenomegaly were noted. No cause for these symptoms was found, although a transient rise in antibody titre to Mycoplasma pneumoniae was noted. An oral cholecystogram was normal. Investigation showed a haemolytic anaemia. She has remained symptom free on folic acid, $5 \mathrm{mg}$ twice weekly.

\section{Methods}

Haemoglobin, haematocrit, red cell indices, red cell count, reticulocyte count, osmotic fragility, autohaemolysis, Coombs's test, and haemoglobin electrophoresis were determined using standard procedures. Assay of glycolytic and shunt related enzymes, and glutathione were performed using standard methods. Red cell membrane cholesterol and phospholipid composition were determined by quantitative 2 dimensional thin layer chromatography.

Red cell sodium and potassium concentrations were determined by flame photometry on cells washed in isotonic $\mathrm{MgCl}_{2}$, using the haemoglobin determined with Drabkins solution to relate values to the haematocrit. Unidirectional sodium and potassium influx was measured as previously described. ${ }^{5}$ Active or pump influx of potassium was taken as the difference between total influx and the influx in the presence of ouabain $(0.2 \mathrm{mmol})$, and cotransport as the bumetanide sensitive fraction. Measurements were made in triplicate on 3 occasions. The effects of hydrostatic pressure and N-ethylmaleimide on potassium influx were determined as previously described. ${ }^{6}$ 
Table Intracellular cation concentrations and cation fluxes (mean $\pm S E M)$

\begin{tabular}{|c|c|c|c|c|c|c|c|c|}
\hline & \multicolumn{2}{|c|}{$\begin{array}{l}\text { Red cell cation } \\
\text { concentrations } \\
\text { (mmol/litre of cells) }\end{array}$} & \multirow{2}{*}{$\begin{array}{l}\text { Sodium influx } \\
\mathrm{Na}=145 \mathrm{mmol} \\
(\mathrm{mmol} / \mathrm{litre} \text { of cells/hr) }\end{array}$} & \multicolumn{5}{|c|}{$\begin{array}{l}\text { Potassium influx } \\
K_{\circ}=7.5 \mathrm{mmol} \\
(\mathrm{mmol} / \mathrm{litre} \text { of cells/hr) }\end{array}$} \\
\hline & $\mathrm{Na}$ & $\boldsymbol{K}$ & & $\begin{array}{l}\text { Ouabain } \\
\text { sensitive }\end{array}$ & $\begin{array}{l}\text { Bumetamide } \\
\text { sensitive }\end{array}$ & Passive & $\begin{array}{l}\text { Passive } \\
400 \\
\text { Atmospheres }\end{array}$ & $\begin{array}{l}\text { Passive } \\
\text { NEM } \\
2 \mathrm{mmol}\end{array}$ \\
\hline $\begin{array}{l}\text { Patient } \\
\text { Normal values }\end{array}$ & $\begin{array}{l}7 \cdot 8 \pm 0 \cdot 2 \\
7 \cdot 9 \pm 1 \cdot 5^{*}\end{array}$ & $\begin{array}{c}113 \pm 4 \\
99 \pm 5^{*}\end{array}$ & $\begin{array}{l}2 \cdot 74 \pm 0 \cdot 23 \\
2 \cdot 0 \pm 0 \cdot 2^{*}\end{array}$ & $\begin{array}{l}1 \cdot 82 \pm 0 \cdot 17 \\
1 \cdot 50 \pm 0 \cdot 20^{*}\end{array}$ & $\begin{array}{l}0.263 \pm 0.017 \\
0.48 \pm 0.15 t\end{array}$ & $\begin{array}{l}0.41 \pm 0.03 \\
0.11 \pm 0.04 \dagger\end{array}$ & $\begin{array}{l}4 \cdot 5 \\
0 \cdot 8-1 \cdot 5 \ddagger\end{array}$ & $\begin{array}{l}9 \cdot 0 \\
0-8-1 \cdot 5 \ddagger\end{array}$ \\
\hline
\end{tabular}

*Taken from Wiley et al. $1975 ; 7$ †ean of 8 normal donors; $\$$ Range for 7 normal donors. NEM $=$ N-ethylmalemeide

Passive fluxes are defined as the residual fluxes in the presence of ouabain and bumetamide. Normal values are representative of determinations in this laboratory and published data as shown.

\section{Results}

At the time of investigation the patient had mild anaemia-haemoglobin concentration $9.3 \mathrm{~g} / \mathrm{dl}$; haematocrit $0 \cdot 27$, associated with reticulocytosis; red cell count $2.7 \times 10^{12} / 1$; and reticulocytes $166 \times 10^{9} / 1$. Red cell indices were in the normal range-mean corpuscular volume $96 \mathrm{fl}$, mean corpuscular haemoglobin $33.8 \mathrm{pg}$, and mean corpuscular haemoglobin concentration $34.7 \mathrm{~g} / \mathrm{dl}$. The peripheral blood smear showed anisocytosis and poikilocytosis. There were no spherocytes, stomatocytes, or target cells. Total leucocytes was $5.4 \times 10^{9} / 1$ $(54000 / \mu \mathrm{l})$ and platelet count $227 \times 10^{9} / 1(227000 / \mu \mathrm{l})$. Plasma bilirubin (indirect) was $50 \mu \mathrm{mol} / 1 \mathrm{l}(2.9$ $\mathrm{mg} / 100 \mathrm{ml}$ ).

There was no evidence of a haemoglobinopathy, shown by normal haemoglobin electrophoresis and normal fractions of haemoglobin $A_{2}(2 \cdot 1 \%)$ and $F$ $(<1 \%)$. The direct Coombs's test, Ham test, and screen for unstable haemoglobin were negative. Haptoglobin was $5 \%$. Osmotic fragility was normal but autohaemolysis was slightly increased by $4.4 \%$ (control $1.6 \%$ ) after 48 hours incubation at $37^{\circ} \mathrm{C}$, and was partially corrected to $1.2 \%$ (control $0.6 \%$ ) by the addition of glucose.

Assay of the following red cell enzymes indicated activity in the normal range: glucose-6-phosphate dehydrogenase, $7.42 \mathrm{u} / \mathrm{gHb}$; 6-phosphogluconate dehydrogenase, $5.96 \mathrm{u} / \mathrm{gHb}$, pyruvate kinase $16.6 \mathrm{u} / \mathrm{gHb}$, glucose phosphate isomerase 41.7 $\mathrm{u} / \mathrm{gHb}$, and hexokinase $1.32 \mathrm{u} / \mathrm{gHb}$. Red cell glutathione concentration was $78 \mathrm{mg} / \mathrm{dl}$ (control $70 \mathrm{mg} / \mathrm{dl}$ ) and 2,3-diphosphoglycerate $2.46 \mu \mathrm{mol} / \mathrm{ml}$. The patient's red cell membrane cholesterol/ phospholipid ratio was (mean \pm SD) $0.70 \pm \mathbf{0 . 0 2}$ (control (mean $\pm \mathrm{SD}$ ) $0.68 \pm 0.03$ ), and phospholipid composition was normal except for a slightly high percentage of phosphatidic acid $(1.9 \%)$ and lysophosphatidyl choline $(3 \cdot 2 \%)$.

Red cell cation content and results of cation flux studies are shown in the Table. Although red cell sodium and potassium concentrations were normal, both passive and mediated fluxes differed from normal values. The most striking deviation was the passive potassium leak, which was raised about threefold. Similarly, the addition of N-ethylmaleimide or high hydrostatic pressure induced a very high passive potassium permeability.

Neither parent had evidence of anaemia. Their haemoglobin concentrations, red cell indices, reticulocyte counts, and autohaemolysis were all normal.

\section{Discussion}

Although red cell lifespan was not measured in this girl, the investigations described provide unequivocal evidence of a congenital haemolytic anaemia. Those conditions known to be associated with both haemolysis and secondary abnormalities of red cell cation transport, such as spherocytosis, sickle cell disease, and pyruvate kinase deficiency were all excluded. It is therefore likely that the observed abnormalities of red cell cation transport represent the primary defect responsible for her anaemia.

Anaemias due to 'leaky' red cells form a heterogeneous group with a wide spectrum of severity. Patients with severe anaemia, massive increases in cation permeability, and highly abnormal red cell cation concentrations have been described. ${ }^{1}$ Increased autohaemolysis has been a consistent finding in all cases, but osmotic fragility varies with the red cell hydration state. This may be increased, normal, or decreased depending upon the relative changes in sodium and potassium permeability and the resultant total cation concentration. The abnormalities observed in this patient under normal conditions were clearly minor and well compensated as red cell cation concentrations and hydration were normal. Although both active and passive cation fluxes were increased in reticulocytes, the degree of reticulocytosis present in this patient at the time of investigation would be insufficient to account for the observed abnormalities. ${ }^{8}$ 
Both the underlying membrane defect and the mechanism of haemolysis in this condition remain obscure. Abnormal red cell deformability, and the increased metabolic demand of a high cation pump rate may both render these cells susceptible to haemolysis, especially in the splenic microcirculation. Splenectomy has been of benefit in some but not all cases. There was no important abnormality of membrane lipid composition. The striking increase in potassium permeability observed in response to increased hydrostatic pressure and incubation with $\mathrm{N}$-ethylmaleimide is of particular interest. Activation of this chloride dependent potassium transport pathway in vivo would certainly lead to cell destruction and it is possible that some pathophysiological analogue of $\mathrm{N}$-ethylmaleimide treatment is partly responsible for haemolysis in this patient. Inhibition of this $\mathrm{N}$-ethylmaleimide induced potassium channel by quinine and quinidine ${ }^{7}$ suggests that these drugs might be of value in ameliorating haemolysis induced by this pathway.

Lipid analyses were carried out by Dr B Roelofsen, Rijksuniversiteit, Utrecht, and red-cell glutathione content was determined by $\mathrm{Dr} \mathrm{E}$ Tucker, Institute of Animal Physiology, Babraham. This work was supported in part by an MRC project grant to JCE.

\section{References}

1 Oski FA, Naiman JL, Blum SF, et al. Congenital hemolytic anemia with high sodium, low potassium red cells. New Engl J Med 1969; 280: 909-16.

2 Lock SP, Sephton-Smith R, Hardisty RM. Stomatocytosis: a hereditary red-cell anomaly associated with haemolytic anaemia. Br J Haematol 1961 ; 7: 303-14.

3 Meadow SR. Stomatocytosis. Proc R Soc Med 1967; 60: 13-5.

- Wiley JS. Genetic abnormalities of cation transport in the human erythrocyte. In: Ellory JC, Lew VL, eds. Membrane transport in red cells. London: Academic Press, 1977: 337-61.

5 Dunham PB, Ellory JC. Stimulation of the sodiumpotassium pump by trypsin in low potassium type erythrocytes of goats. J. Physiol 1980; 301:25-37.

- Ellory JC, Dunham PB, Logue PB, Stewart GS. Anion dependent cation transport in erythrocytes. Proc $R$ Soc Lond [Biol] 1982; 299: 563-71.

7 Wiley JS, Ellory JC, Shuman MA, Shaller CC, Cooper RA. Characteristics of the membrane defect in the hereditary stomatocytosis syndrome. Blood 1975; 46: 337-56.

8 Bernstein RE. Alterations in metabolic energetics and cation transport during aging of red cells. $J$ Clin Invest $1959 ; 38$ : 1572-86.

Correspondence to Dr N D Barnes, Department of Paediatrics, Addenbrooke's Hospital, Hills Road, Cambridge CB2 2QQ.

Received 2 February 1983 